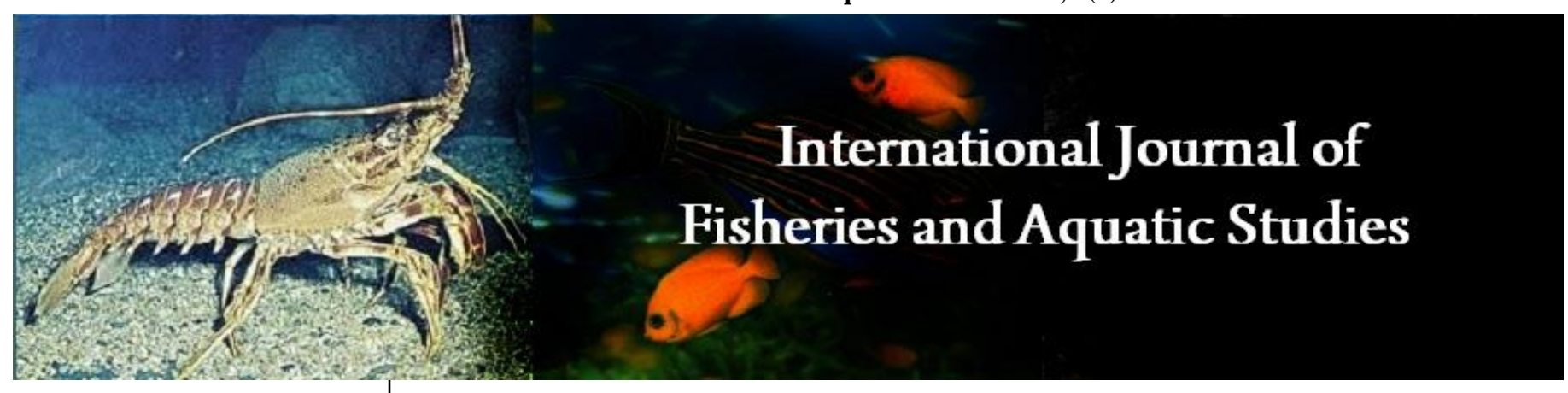

E-ISSN: 2347-5129

P-ISSN: 2394-0506

(ICV-Poland) Impact Value: 5.62

(GIF) Impact Factor: 0.549

IJFAS 2021; 9(2): 168-179

(C) 2021 IJFAS

www.fisheriesjournal.com

Received: 10-01-2021

Accepted: 12-02-2021

Bandla Seshagiri

Regional Research Centre, ICAR-

Central Institute of Freshwater

Aquaculture, Poranki, Vijayawada,

Andhra Pradesh, India

\section{Sudhansu S Mishra}

Fish Health Management Division,

ICAR-Central Institute of Freshwater

Aquaculture, Bhubaneswar, Odisha,

India

Saroj Kumar Swain

Aquaculture Production and

Environment Division, ICAR-Central

Institute of Freshwater Aquaculture,

Bhubaneswar, Odisha, India

Bindu R Pillai

Aquaculture Production and

Environment Division, ICAR-Central

Institute of Freshwater Aquaculture,

Bhubaneswar, Odisha, India

Chintada Satyavati

Regional Research Centre, ICAR-

Central Institute of Freshwater

Aquaculture, Poranki, Vijayawada,

Andhra Pradesh, India

Y Sravanti

Regional Research Centre, ICAR-

Central Institute of Freshwater

Aquaculture, Poranki, Vijayawada,

Andhra Pradesh, India

PV Rangacharyulu

Regional Research Centre, ICAR-

Central Institute of Freshwater

Aquaculture, Poranki, Vijayawada,

Andhra Pradesh, India

Ramesh Rathod

Regional Research Centre, ICAR-

Central Institute of Freshwater

Aquaculture, Poranki, Vijayawada,

Andhra Pradesh, India

\section{Ratnaprakash}

Krishi Vigyan Kendra,

Vinayashramam, Kavuru, Guntur,

Andhra Pradesh, India

Corresponding Author: Bandla Seshagiri

Regional Research Centre, ICAR-

Central Institute of Freshwater

Aquaculture, Poranki, Vijayawada,

Andhra Pradesh, India

\section{Sustainability of striped catfish (Pangasianodon hypophthalmus, Sauvage, 1878) culture in Andhra Pradesh, India}

\author{
Bandla Seshagiri, Sudhansu S Mishra, Saroj Kumar Swain, Bindu R \\ Pillai, Chintada Satyavati, Y Sravanti, PV Rangacharyulu, Ramesh \\ Rathod and V Ratnaprakash
}

DOI: https://doi.org/10.22271/fish.2021.v9.i2c.2443

\begin{abstract}
In spite of vast diverse fish genetic resource of India, several exotic species have been introduced into India. Chinese carps which were introduced in India with an objective of increasing the yields in aquaculture has paved way for composite fish culture in India. Introduction of exotic species for fisheries and aquaculture was successful in some instances while in few situations, it failed leading to controversy over protection of native biodiversity. Pangasius (Pangasianodon hypophthalmus) an exotic species has been introduced into India and is not only adopted for culture in states like West Bengal and Andhra Pradesh but also established as an alternative candidate species in freshwater aquaculture. Fish seed production segment in West Bengal played a pivotal role in the expansion of Pangasius farming in Andhra Pradesh. Pangasius monoculture was found to be profitable in comparison to polyculture with carps and other fishes. Use of formulated feeds is the major choice of Pangasius farmers. Pangasius catfish is less prone to diseases when compared to carps and is sensitive to abiotic stress. Comparatively, low market value of Pangasius than carps has increased avenues of fish consumption by low income consumers. Very fast development in culture of Pangasius has created many challenges such as dearth of quality seed, inconsistent management practices, prevalence of stress induced diseases, glut in the market and acute decline in the farm gate price leading to stabilization of farming area in Andhra Pradesh. Pangasius farming in Andhra Pradesh is sustaining due to strategic stocking and harvesting pattern adopted by the farmers conforming to market trend. Inappropriate practices in order to achieve higher yields and input-specific technical inefficiency are associated with the economic losses while minimizing the use of inputs can reduce risk factors in Pangasius farming. It is important to record that demand for carp culture in Andhra Pradesh is still greater in spite of less complications underlying in Pangasius farming and management.
\end{abstract}

Keywords: exotic species, pangasius, diversification, sustainability, compatibility

\section{Introduction}

Introduction of exotic fish species is a common tool in many parts of the world for improving local fishery potential, expanding species diversity in aquatic systems, promoting sport fishing, increasing aquarium trade and as biological controlling agents (Kumar, 2000, Singh and Lakra, 2012) ${ }^{[1,2]}$. Cross-country transfer of fishes raised global concern as it result in a wide range of problems including displacement of native species (Raman et al., 2013) ${ }^{[3]}$. Exotic species in several instances have become competitors for indigenous fishes for food as also habitat by sharing common ecological niches (De Silva, 1989; Rafferty, 2019) ${ }^{[4,5]}$. In some instances they even prey upon indigenous fishes, harbor new diseases and parasites and sometimes, resulting in the production of hybrids and thus not only leads to degradation of the quality of the aquatic ecosystems but increase threat to existing biodiversity (Nyman, 1991) ${ }^{[6]}$. The potential risks might not limit to qualitative and quantitative biodiversity but become detrimental to socioeconomic issues related to the human community that depend on aquatic ecosystems for their livelihood. There are instances that invasive species not only modified but disrupted the ecosystems in which it colonizes (Philipp et al., 1995) ${ }^{[7]}$. Global commerce is the most common tool by which, exotic species are recruited in new habitats (Rafferty, 2019) ${ }^{[5]}$ 
Striped catfish (Pangasianodon hypophthalmus) was introduced into Andhra Pradesh by seed sellers from West Bengal, India as early as 1995 (Ramakrishna et al., 2013; Singh and Lakra, 2012) ${ }^{[8,2]}$. Initially, it was incorporated into Indian major carp polyculture systems but over time, it has transformed into monoculture due to higher growth rates and production levels, Currently, Pangasius culture in Andhra Pradesh has evolved as the second most important culture system in the stat with currently estimated production of 400 000 tonnes per annum (Belton et al., 2017; Ramakrishna et al, 2013) ${ }^{[9,8]}$.

\section{Methods and Methodology}

Importance of review articles that synthesize existing data and generate guidelines is increasing in contemporary science (Palmatier et al., 2018) ${ }^{[10]}$. Present article is an integrated attempt that discussed theoretical and practical contributions besides comprising experimental data of authors pertaining to Pangasius catfish (Pangasianodon hypopthalmus) farming in Andhra Pradesh, India. We have consulted one hundred original works that were carried out mostly during the past two decades (2000-2020) with few exceptions on the subject of interest and quoted $96 \%$ of the original works while formatting and interpreting the accrued data.

This paper is also conjointly based on an investigative study on the Pangasius breeding and farming in Andhra Pradesh that was carried-out during 2011-2016 further authenticated by Focus Group Discussions (Krueger and Casey, 2000) [11] during 2016-2019. Present study (Fig.1) includes information accrued from interviews with Pangasius farmers (55\%), Seed growers (15\%), Farm labour (6\%), Fish packers and Traders including ice factory owners $(8 \%)$, Feed manufacturers and dealers $(6 \%)$, aquaculture technicians and consultants $(6 \%)$ and government officials (4\%). Consistency levels in the opinions expressed by the respondents were confirmed in repeat interviews conducted on $10 \%$ of the original sample in follow-up round (Benedetti et al., 2010) ${ }^{[12]}$

\section{Introduction of Exotic Fish Species}

Despite the vast divergence in indigenous fish genetic resources, more than 300 exotic species have been introduced in India from other countries (Jhingran, 1991) ${ }^{[13]}$. Most of them are ornamental fishes which remain, more or less, confined to the aquaria while some others have been introduced in aquaculture and open water systems with varying levels of success (Choudhary and Goswami, 2012) [14]. Chinese carps viz., Silver carp (Hypophthalmichthys molitrix), Grass carp (Ctenopharyngodon idella) and Common carp (Cyprinus carpio) were introduced in India with the aim of expanding the species spectrum in aquaculture (Sugunan, 2011) ${ }^{[15]}$ andenhancing the fish yields through optimum utilization of trophic niches (Jhingran, 1991; Choudhary and Goswami, 2012) ${ }^{[13,14]}$. Subsequently, six species composite fish culture was widely accepted in the country due to significant enhancement in unit production levels (Pillai and Katiha, 2004) ${ }^{[16]}$. Although, exotic carps viz., Silver carp, Grass carp and Common carp have become established in Indian culture systems due to their compatibility with Indian Major Carps, but their involvement in pond culture systems have undergone extensive refinement and modification (Soranganba and Saxena, 2007) ${ }^{[17]}$. Recruitment of exotic fishes into the open waters has become debatable due to detrimental impact on the fish species diversity of the Indian rivers (Bhattacharjya et al., 2017;
Sarkar et al., 2015) ${ }^{[18,19]}$. Inclusion of exotic species in fisheries and aquaculture as tools of diversification is successful in some instances (Bhatt and Singh, 2014) [20] while in few cases have failed leading to controversy over protecting the native biodiversity (Jena and Gopalakrishnan, 2012) [21]. Exotic species such as Tilapia (Oreochromis mossambicus) has become great menace in pond culture systems and affected carp growth resulting in severe low unit production incurring heavy losses to the farmer (Ramakrishna et al., 2013) ${ }^{[8]}$. Similarly, invasion of sucker-mouth catfish (Pterygoplichthys disjunctivus) into carp culture systems in Andhra Pradesh retarded fish growth significantly by $30 \%$ besides imposing environmental stress, exhibiting direct competitive interaction through disrupting aquatic food chain and reduce food availability in the ponds (Hussan et al., 2016; Singh, 2014) ${ }^{[22,23]}$ as well as rivers (Meena et al., 2016) ${ }^{[24]}$.

\section{Striped Catfish /Pangasius (Pangasianodon hypophthalmus)}

Pangasianodon hypophthalmus, an exotic species of freshwater catfish (Family: Pangasiidae, Order: Siluriformes, Class: Actinopterygii) was introduced into India and has been adopted for culture in states like West Bengal and Andhra Pradesh (Ayyappan et al., 2015, Ramakrishna et al., 2013; Singh and Lakra, 2012) ${ }^{[25,8,2]}$ in view of variety of reasons viz., (i) faster growth rate of attaining $1.5 \mathrm{~kg}$ in 6 months, (ii) less cost of production, (iii) sustain DO stress and other factors. Consumer preference of Pangasius $(P$. hypopthalmus)was attributed to less number of inter muscular bones in the flesh. Culture of Pangasius has been officially admitted in Indian waters by Govt. of India in 2009 through formulation of guidelines (NFDB, 2009) ${ }^{[26]}$. Northeastern states functioned as gateway for unauthorized introduction of alien fish species to India from Bangladesh, Thailand (Chattopadhyay, 2016; Singh and Lakra, 2012) ${ }^{[27,2]}$. The species preferred for transfer include African catfish (Clarias gariepinus); Thai catfish (Clarias macrocephalus); Pangasid catfish (Pangasianodon hypopthalmus); Pacu (Piaractus brachypomus) and white-leg shrimp (Litopenaeus vannamei) out of which Pangasius culture has shown phenomenal growth during 2009-2010 reaching 16,000 $\mathrm{Ha}$ in Andhra Pradesh alone with production of 0.6 million MT fish. Most of the fish farmers in Krishna-Godavari Delta have adopted Pangasius farming as an alternative to carp culture in the areas such as (i) which have suffered losses in shrimp farming and (ii) less productive areas (Belton et al., 2017) ${ }^{[9]}$. Dimensions of poorly regulated expansion in Pangasius culture in Andhra Pradesh has resulted in social-ecological as also created huge economic crisis (Padiyar et al., 2014) ${ }^{[28]}$. Huge supply of Pangasius fish has caused prices to crash by more than $50 \%$ and resulted in heavy losses to small farmers who exited from Pangasius farming subsequently (Belton et al., 2017) ${ }^{[9]}$. The market avenues for the Pangasius are scanty and limited (Mugaonkar et al., 2016) [29] when compared to the wellestablished trading network and consumer markets of the Indian major carps, As a result, farming of Pangasius $(P$. hypophthalmus) is now restricted to 14,000 ha (Fig. 2) covering approximately $7-8 \%$ of the total fish culture area in Krishna-Godavari Delta region with stabilized production of 250,000 tonnes (Fig. 3). Very fast development in culture of Pangasius has created many challenges such as dearth of quality seed, inconsistent management practices, prevalence of stress induced diseases, glut in the market and acute decline in the farm gate price. These problems have warranted 
the need for developing a sustainable hatchery technology, production of quality seed and standardization of nursery and rearing practices. Famers in Andhra Pradesh and West Bengal have accepted Pangasius as profitable species in aquaculture owing to its faster growth and less complications in culture operations (Jayasankar and Giri, 2013) ${ }^{[30]}$.

\section{Seed Production of $P$. hypopthalmus}

West Bengal state has become the focal point in seed production of $P$. hypophthalmus in the country with seed production capacities ranging from 300 to 500 every year. Large volumes of seed is exported to Andhra Pradesh followed by Bihar, Chhattisgarh, Kerala, Rajasthan, Uttar Pradesh and Karnataka states. Seed production of $P$. hypophthalmus is not only used for culture but is also sold for the aquarium trade (Singh and Lakra, 2012) ${ }^{[2]}$. Production per hectare per year in Pangasius culture in ponds is known to range from 7 to 50 tonnes (Griffiths et al., 2010) ${ }^{[31]}$. Fish seed production segment in West Bengal played pivotal role in catalyzing the expansion of Pangasius farming in Andhra Pradesh (Ali et al., 2013) ${ }^{[32]}$. Fish seed traders from West Bengal were able to fulfill 2 billion demand for Pangasius seed supply in Andhra Pradesh sourced from trans-border hatcheries (Padiyar et al., 2014; Tam et al., 2010) ${ }^{[28,33]}$. Seed contributes to second most important cost that accounts for 12 to $14 \%$ of cultivation cost (Mugaonkar et al., 2019) ${ }^{[34]}$. This is higher than the cost incurred by farmers in Bangladesh (Alam, 2011) ${ }^{[35]}$. Additional premium paid by Pangasius farmers in Andhra Pradesh involved transportation costs from West Bengal. Establishment of hatchery and seed production facilities for Pangasianodon hypopthalmus in Andhra Pradesh has demonstrated commercial scale production of Pangasius seed through induced breeding (ICAR, 2013) [36]. Subsequently, establishment of one large commercial hatchery facility under private sector in Andhra Pradesh during 2018 has minimized dependency on West Bengal to $30 \%$.

\section{Mono and Polyculture of Pangasius (P. hypopthalmus)}

Farmers hailing from Krishna and West Godavari districts of Andhra Pradesh are culturing Pangasius in ponds ranging from 4 to 10 ha (Fig. 4). Although Pangasius is cultivated under monoculture as well as in combination with Indian major carps, monoculture was found to be profitable and uncomplicated. Therefore, most of the farmers have adopted monoculture practice. In polyculture system Pangasius and Rohu are incorporated in 95:5 ratio at a density of $25000 / \mathrm{Ha}$ and 1,250/Ha respectively (Nair and Salin, 2007) ${ }^{[37]}$. Higher stocking of rohu in mixed culture has hampered its growth due to shortage in the availability of feed. Although several experiments established profitability in Pangasius polyculture in combination with Rohu and Catla (Ali et al., 2016; Azad et al. 2004; Shafiullah et al., 2019) [38, 39, 40], Freshwater Prawn (Islam et al., 2008) ${ }^{[41]}$ but farmers by and large preferred monoculture of Pangasius. Although compatibility of Pangasius polyculture with white-leg Shrimp (Litopenaeus vannamei) was successfully demonstrated by some farmers under field conditions, it could not be practiced due to operational difficulties and loss of control over overheads.

Polyculture of $P$. hypophthalmus is confined to low-salinity shrimp ponds abandoned after the white spot syndrome (WSS) virus outbreaks in Andhra Pradesh (Nair and Salin, 2007) ${ }^{[37]}$. Rohu (L. rohita) and catla (Catlacatla) tolerate salinities up to 8ppt (Ali et al., 2015) ${ }^{[42]}$ while Pangasius grow well even in 13 ppt (Castaneda et al., 2010; Jahan et al., 2019) ${ }^{[43,44]}$ and can tolerate up to 23 ppt (Nair and Salin, 2007) ${ }^{[37]}$. However, grow-out under higher salinities can confer a darker coloration to carp, which is not desirable in the market. Over the years, it was recorded that there was a shift in culture practice to Pangasius in some of the areas in Andhra Pradesh due to less management problems, higher productions and closure of shrimp ponds due to disease outbreaks and frequent crop failures. Not only farmers who suffered heavy losses in shrimp farming but also farmers performing carp culture in inland command areas have adopted $P$. hypophthalmus farming as an alternative to carp farming. Cost of production in Pangasius has increased by almost $200 \%$ due to escalation in cost of inputs and hasimpacted marginal farmers and their socio-economic conditions. At the same time, improper methods to achieve higher fish yield and input-specific technical inefficiency also associated with the economic losses in Pangasius farming (Khan et al., 2017; Ngoc et al., 2018) [45, 46]. Similarly, polyculture of pacu (Piaractus brachypomus) which is introduced illegally in India is another emerging aquaculture practice in Andhra Pradesh (Singh, 2018) [47] next to Pangasius. However, it is interesting to record that demand for carp culture in Andhra Pradesh is still greater to the extent of $69.5 \%$ (Fig. 5) in spite of uncomplicated culture operations in cultivating $P$. hypophthalmus $(6.5 \%)$.

\section{Diseases in Pangasius Catfish}

Despite, Pangasius is an air-breathing catfish but maintenance of optimum water quality in culture ponds should not be ignored because it is found to be very sensitive to abiotic stress, mostly due to ammonia toxicity (Azad et al., 2004) ${ }^{[39]}$. However, when compared to carps, it is able to sustain poor water quality conditions (Faruk, 2008) ${ }^{[48]}$. Deterioration in water quality and low water temperatures will enhance the risk of parasite (Lakra and Singh, 2010; Swain, 2017) ${ }^{[48,49]}$ and bacterial infections (Singh and Lakra, 2011; Dung et al., 2008) ${ }^{[50,51]}$. Although disease outbreak is not uncommon in Pangasius, instances of mass mortalities are rare in Pangasius ponds unlike carp culture that result in heavy fish mortality. The average estimated economic loss due to diseases was $3.6 \%$ of the total income to farmers (Faruk et al., 2017) ${ }^{[52]}$ as against $14 \%$ in carp farming (Faruk, 2008) ${ }^{[48]}$ besides huge mortalities in carp culture due to diseases (Mishra et al., 2018) ${ }^{[53]}$ and retarded growth (Sahoo et al., 2013) ${ }^{[54]}$.

Pangasius was found to be most commonly infected with myxozoan parasites (Baska et al., 2009; Molnar et al., 2006) ${ }^{[55,56]}$. P. hypopthalmus is prone to diseases in all stages of life cycle but high mortalities occur in fingerlings and juvenile fish (Dung et al., 2008) ${ }^{[51]}$. Disease management in Pangasius farming is done using antibiotics as well as probiotics (Mishra et al., 2017; Singh and Lakra, 2012) ${ }^{[57,2]}$. Although relatively easy management and culture operations prompted fish farmers to adapt Pangasius culture in the region, small and marginal farmers are incurring economic losses due to escalating costs for feed and health management when compared to large farmers (Khiem et al., 2010; Lakra and Singh, 2010) ${ }^{[58,48]}$. But, economic loss in Pangasius farming is recorded not more than $2.5 \%$ in Andhra Pradesh. At the same time, disease occurrence has no relevance to pond size. It was recorded that $45 \%$ farmers faced disease problem in winter while $15 \%$ of farmers reported occurrence of diseases during summer. Forty percent farmers have expressed that although, diseases in Pangasius farming are high during low 
temperatures but pathogenesis and occurrence of various diseases follows no seasonality. Red disease (28\%) was found to be predominant problem encountered by Pangasius farmers followed by Bloat (16\%), Ammonia stress (15\%), Columnaris $(10 \%)$, Flukes (10\%), Dropsy (9\%), Skin ulcers $(8 \%)$ and $4 \%$ other non-specific problems (Fig. 6). Concern in the farming sector is increasing about the long term sustainability of Pangasius farming because of increase in the occurrence of diseases and their negative impact on delivering socioeconomic perspectives. This warrants the need for understanding status of antimicrobial resistance and the transfer of genetically mobile antibiotic-resistant genes in Pangasius farming (Dung et al., 2008) ${ }^{[51]}$

\section{Feeds and Feeding Practices}

Pangasius is cultured using feeds in which protein content ranges from 28to 32\% that mostly consist of cereals (Kader et al., 2003; Sayeed et al., 2009) ${ }^{[59,60]}$. Earlier studies revealed that digestibility of soybean meal by striped catfish are $94.4 \%$ when compared to blood meal, meat and bone meal (Nguyen, 2013; Tran et al., 2010) [61, 62]. Hence, soy meal ingredients form major source of protein in Pangasius feeds (Da et al., 2013) ${ }^{[63]}$. Pangasius can also be cultured using farm made feeds (Nguyen, 2013) ${ }^{[61]}$. Most of the farmers in Andhra Pradesh accounting to $88 \%$ use commercially prepared formulated feeds as against $12 \%$ of farmers use farm made feeds. Similar conditions prevail in other countries (Le and Pham, 2006) ${ }^{[64]}$. However, Faruk et al. (2017) ${ }^{[65]}$ found that use of farm made feeds results in over-feeding as well as wastage that subsequently result in deterioration of water quality. Hence, effective combinations of two types of feed could aid in optimizing the feed utilization and thereby reducing cost incurred. The low input diet of Pangasius made from locally available ingredients reflects an advantage in terms of reduced feed costs (Khan et al., 2009) [66], minimizescost of production as well as ensures ecofriendly produce (Ahmed et al., 2013) ${ }^{[67]}$. Commercially produced pellet feed is the major choice of large farmers in Andhra Pradesh. Small and marginal farmers are incurring economic losses due to escalating costs for feed and health management when compared to large farmers (Lakra and Singh, 2010) ${ }^{[48]}$ since feed in Pangasius farming accounts for $80-85 \%$ of total production cost (Griffiths et al., 2010) [31]. Few farmers prepare their own feed with customized formula. This practice is reducing cost of production by $6-8 \%$. Thus, feed cost can be significantly reduced by resorting to farm made feeds (Jayasankar, 2018) ${ }^{[68]}$.Some fish farmers maintain a feeding enclosure in each pond while using floating feeds. Feed pellets are broadcasted inside the enclosure so that pellets do not drift and accumulate in the shoreline of the pond due to wind action. Thus, feed is not only easily accessible to the fishes in a feeding zone but also prevent feed wastage (Sarvanan et al. 2012) ${ }^{[69]}$. Wet Distillery Grains (WDG) were used as Pangasius feed primarily as an energy, protein and digestible phosphorus source instead of fish meal and other expensive dietary energy ingredients. However, use of WDG did not gain popularity as fish feed due to various reasons such as variability in nutrient content (Shurson, 2012) ${ }^{[70]}$, limiting essential amino acids (Lim and Aksoy, 2008) [71], yellow pigmentation of meat (Banrie, 2013) ${ }^{[72]}$ and very small shelf life due to which it spoils rapidly (Wadhwa and Bakshi, 2016) ${ }^{[73]}$ besides increased ammonia and nitrite content in Pangasius culture systems.

\section{Ornamental value of P. hypopthalmus}

Striped catfish, Pangasianodon hypophthalmus is well known among home aquarists as the "Iridescent shark/Tiger Shark" in aquarium trade has achieved impressive adoption as a commercial aquaculture species since they are hardy (Bailey, 2021, McGee, 2010) [74, 75] and account to $15-20 \%$ of aquarium trade in Andhra Pradesh besides having export value as indigenous ornamental fish (Gupta and Banerjee, 2012) ${ }^{[76]}$ to other states like Tamilnadu. However, aquarium owners have agreed that Tiger Sharks are not easy fish to keep since the fish has instinct of blind hit against aquarium wall leading to injuries that may result in sinking of fish to the bottom, where it may lie till the recovery or sometimes die (Axelord and Leonard, 1996) [77]. Albino varieties of Pangasianodon hypophthalmus (White Tiger Shark) fetch five times premium price than dark pigmented young ones. Some of the compatible tank mates for Pangasianodon hypophthalmus include other large fish such as Arowanas, Datnioides and large Cichlids (Bailey, 2021) ${ }^{[74]}$.

\section{Economics and Market value}

The major determinants of Pangasisus production are feed, seed, farm size, labour, land lease and days of culture (Fig. 7). Cost of production in Pangasius farming is $20 \%$ higher in large farms than small and marginal farms (Mugaonkar et al., $2019)^{[34]}$. Feed accounts for $80-85 \%$ of total production cost for farmers (Alam, 2011; Nguyen, 2013) ${ }^{[35,61]}$ followed by seed which is second most important cost and accounts for 6$8 \%$ of cultivation cost while Mugaonkar et al. (2019) [34] estimated that seed cost contributes to $12-14 \%$ of production cost.The cost of casual human labour on overall basis accounts for about 2-3\% of total variable cost (Alam, 2011) [35]. Extension of culture period is resulting in increase of production cost by $10 \%$ as against $4 \%$ increase in fish production. Average production cost of Pangasius in Andhra Pradesh accounts to INR 65-70 per kilo of fish with production levels of 35 tonnes per hectare. Production cost of Pangasius in India, has increased by $190 \%$ since the inception of culture in 2004 . Farm-gate price also increased by $180 \%$ by 2020 except for extreme inconsistency in offering remunerative prices (Fig. 8). Production costs have increased by $180 \%$ in various countries due to increase in input costs (Merican, 2020; Mugaonkaret al., 2019) [78, 34]. Simultaneously, profits in Pangasius culture have declined from $54 \%$ in 2004 to $18 \%$ in 2019 . Exceptionally, farmers have incurred loss of 9\% during COVID Pandemic (Fig. 9). In spite of highly fluctuating markets in India (Mohan et al.,2019) ${ }^{[79]}$ as well as other countries (Thong et al., 2020) [80], Pangasius farming in Andhra Pradesh is sustaining due to strategic stocking and harvesting pattern adopted by the farmers corresponding to market trend (Mohan et al., 2019) [79].

Comparatively, low market value of Pangasius when compared to carps has increased avenues of fish consumption by low income consumers. Initially the market was limited to the Northeast states in India but expanded to Uttar Pradesh, Bihar, Jharkhand and Madhya Pradesh and Maharashtra. Now, Ghazipur (New Delhi) has become one of the major markets for Pangasius trading in India. Frequent fluctuations in farm gate prices followed by severe collapse in market during 2009-2011 have totally restructured the Pangasius value chain. Feed manufacturers have started vertical integration by initiating Pangasius farming by themselves. Few feed manufacturers have promoted buy back and 
marketing of Pangasius produced by their customer chain. This signaled the initiation of contract or quasi-contract farming contracts (Mugaonkar et al., 2017) ${ }^{[81]}$ which were in vogue in other countries (Hasan et al., 2019) ${ }^{[82]}$.

\section{Presence of $P$. hypopthalmus in natural waters}

Presence of few specimens of $P$. hypopthalmus has been recorded from the wild in Andhra Pradesh and wetlands in West Bengal. Bench mark surveys carried out in India have indicated the availability of $P$. hypopthalmus in natural waters (Singh and Lakra, 2012) ${ }^{[2]}$. Presence of similar chromosome number $(2 \mathrm{n}=60)$ in Pangasius pangasius, a native species in India and $P$. hypophthalmusas well as overlapped spawning period may facilitate hybridization resulting in genetic mosaicism (Lakra and Singh, 2010) ${ }^{[48]}$, introgression and genetic bottle necks (Pandit and Raul, 2019) ${ }^{[83]}$ in case of establishment of latter in natural waters (Sarkar et al., 2017) ${ }^{\text {[84] }}$. This may not be difficult since cross breeding between $P$. pangasius and $P$. hypophthalmus was successfully demonstrated in Bangladesh (Khan and Mollah, 2004; Hossain et al., 2019) ${ }^{[85,86]}$. Hence, present occurrence of $P$. hypopthalmus in natural waters warrants further studies with regard to the ecological conditions and its impact on native

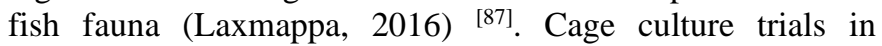
Maharashtra (Ujni Dam), Jharkhand (Chandil) and Chattisgarh (Jumka) established potentials of Pangasius cage

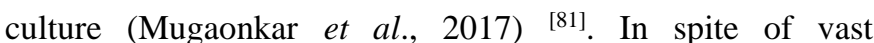
potentials, cage culture trials in reservoirs in Andhra Pradesh and Telangana were not encouraging (Kummari et al., 2018; Sarkar et al., 2017) ${ }^{[88,84]}$. Although, P. hypopthalmus is a candidate species for cage culture in reservoirs in India (Bhendarkar et al., 2017; Kumar et al., 2015) ${ }^{[89,90], \text { requires }}$ thorough studies since, in India, the river ecosystems which are already invaded by exotic species (Jacob et al., 2020) [91] are subjected to severe stress (NFDB, 2016) ${ }^{[88]}$ posing to habitat loss or degradation due to spectrum of reasons such as deforestation, construction of dams, water abstraction, low inflows and pollution from industrial, domestic and agricultural runoff (Hughes, 2017; Zeng et al., 2017) ${ }^{[93,94]}$.

\section{2. $P$. hypopthalmus as a biological to control weed fish}

Sucker mouth armoured catfish which has become great menace in carp culture ponds in Andhra Pradesh resulting in $20 \%$ drop down of fish production, did not exist in ponds where Pangasianodon hypopthalmus culture is going on (Giri et al., 2021) ${ }^{[95]}$. Although few studies have indicated that large predatory fish such as Pangasius sanitwongsei be useful for controlling sucker mouth armoured catfish (Pterygoplichthys spp) but was found to be ineffective as a predator on Pterygoplichthys pardalis that measure a length of $10 \mathrm{~mm}$ and above because of their relatively large pectoral and dorsal spines (Chaichana and Sirapat, 2012) ${ }^{[96]}$.

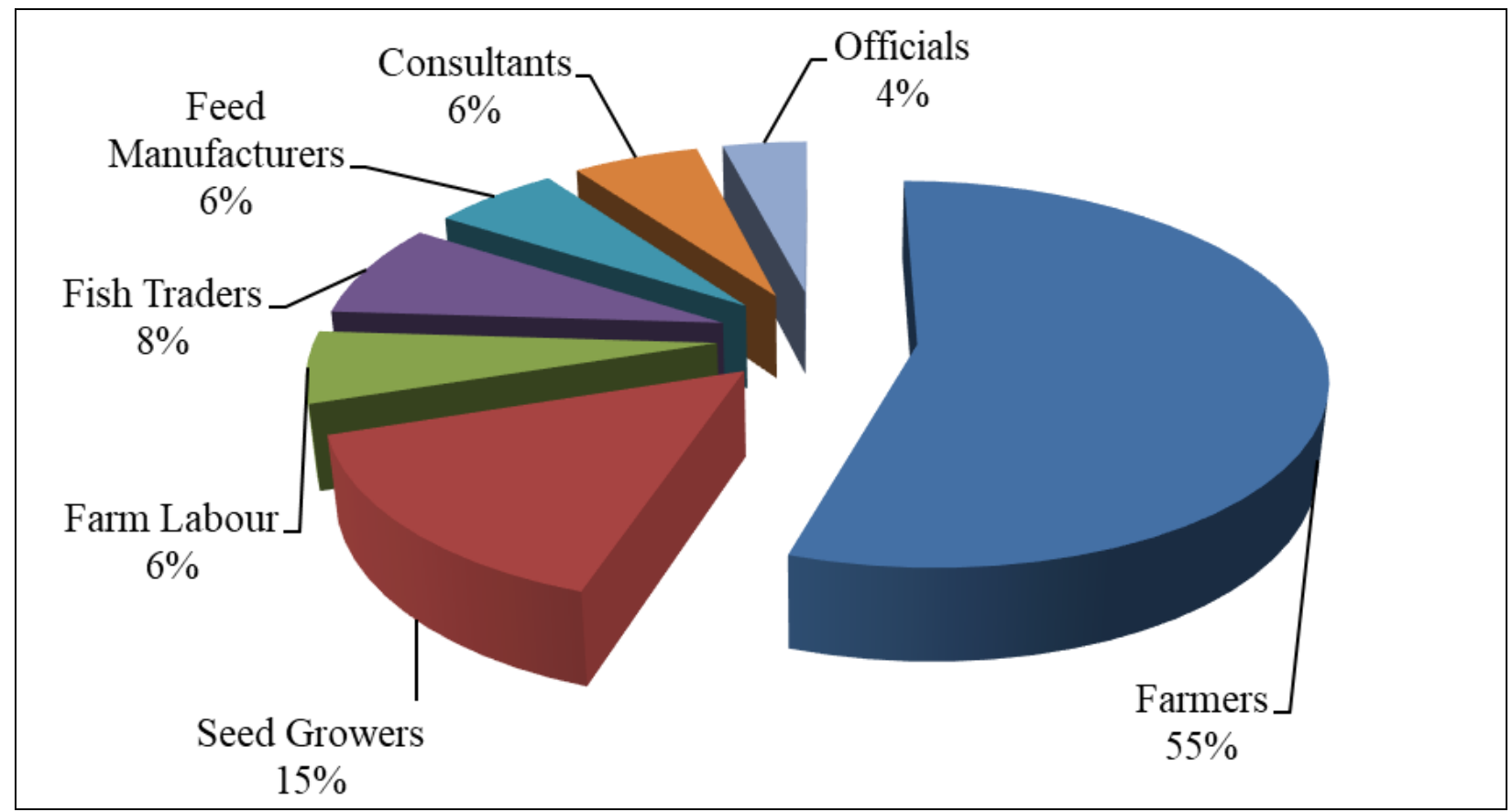

Fig 1: Pie chart showing percentage of respondents who participated in survey regarding Pangasius farming in Andhra Pradesh, India 


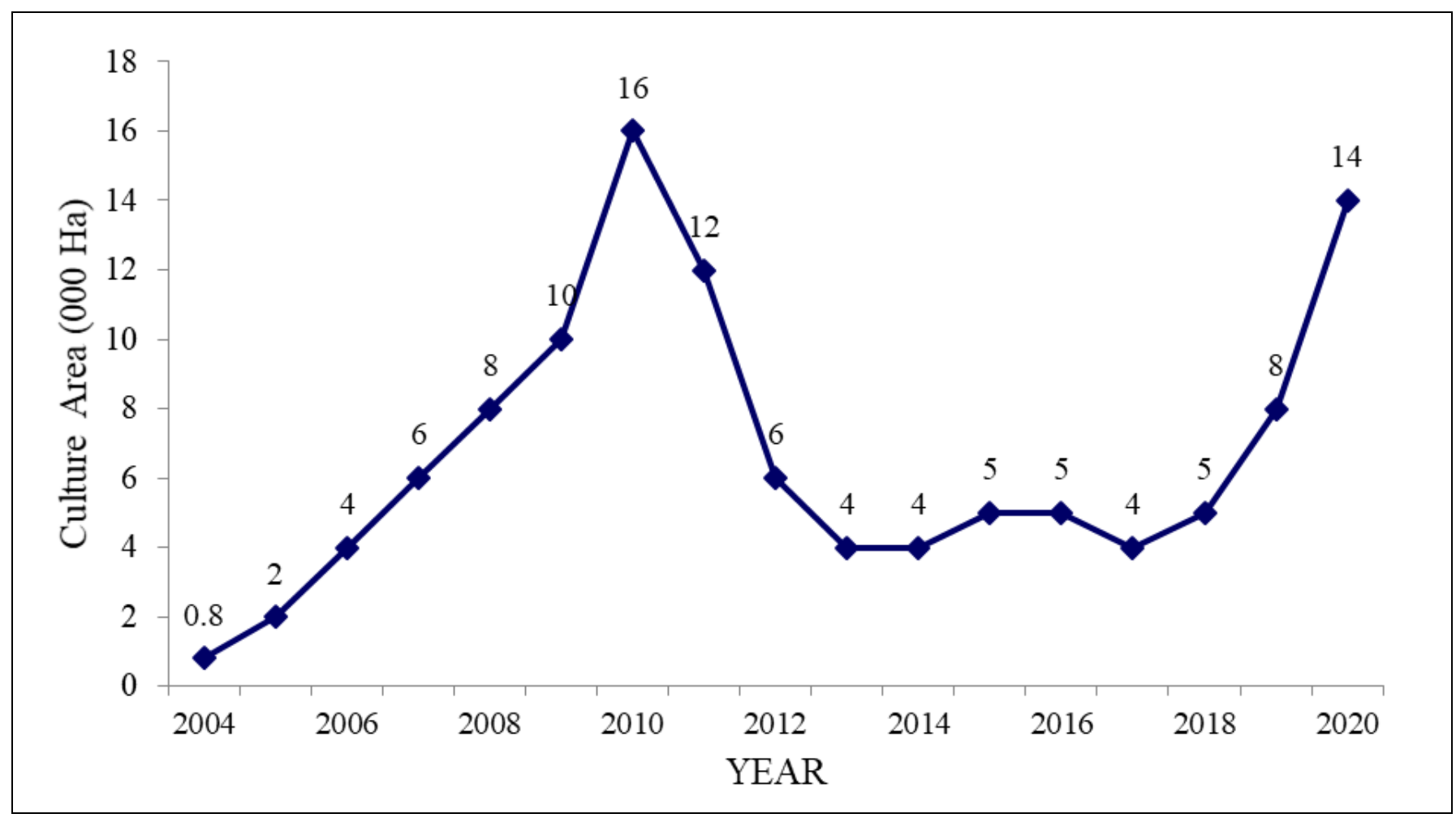

Fig 2: Line drawing showing Pangasius culture trend over the years in Andhra Pradesh, India

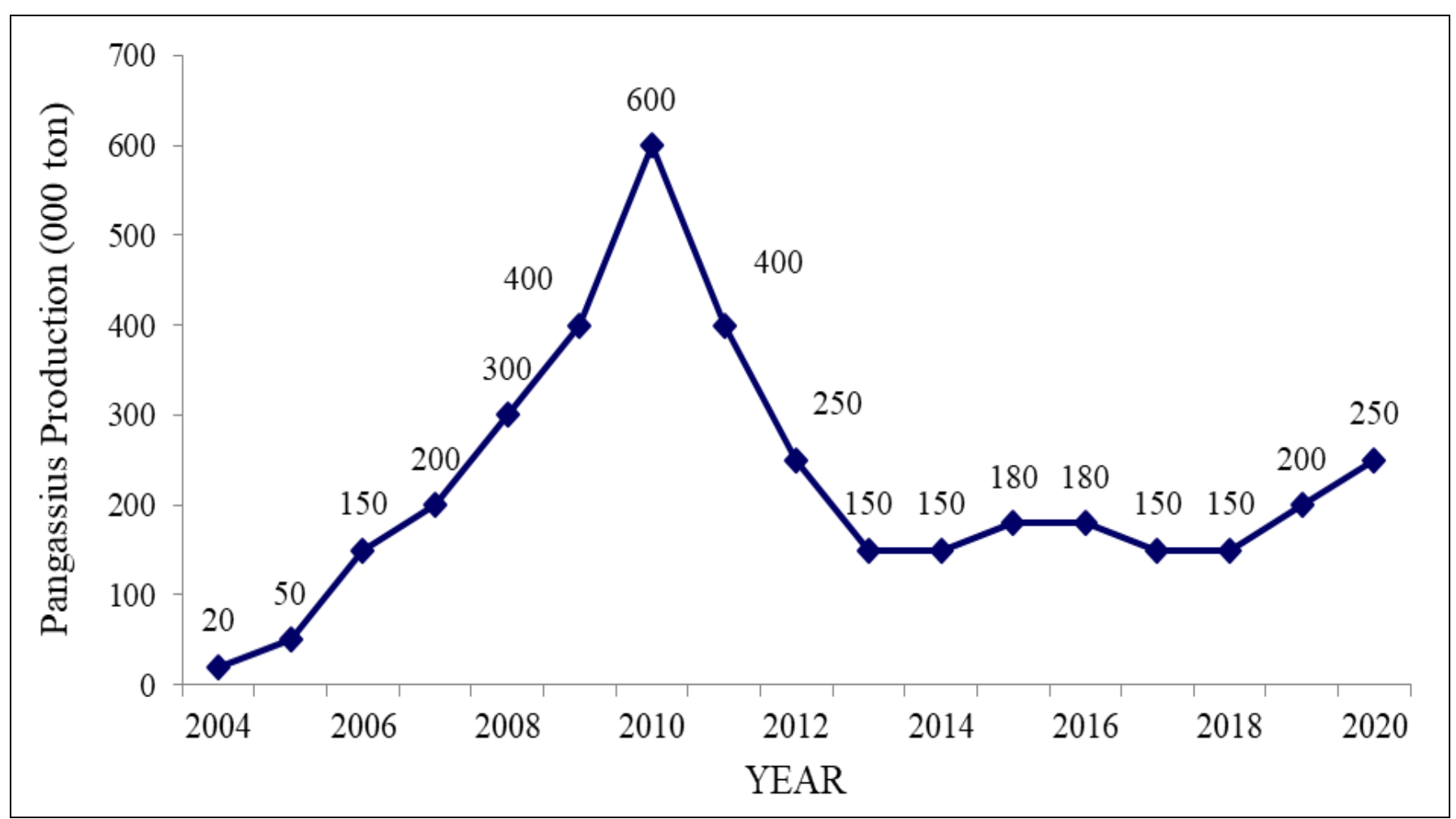

Fig 3: Line drawing showing Pangasius production figures over the years in Andhra Pradesh 


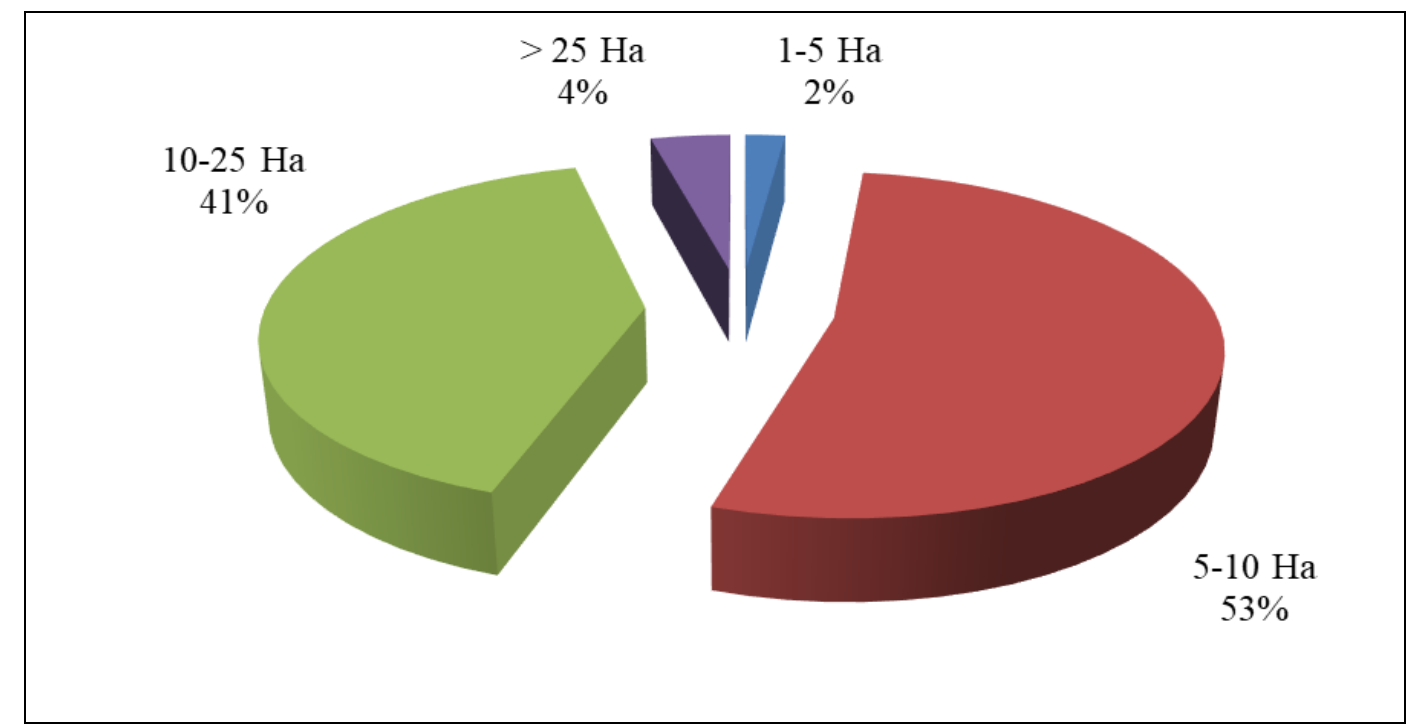

Fig 4: Pie chart showing land holding of Pangasius farmers in Andhra Pradesh, India

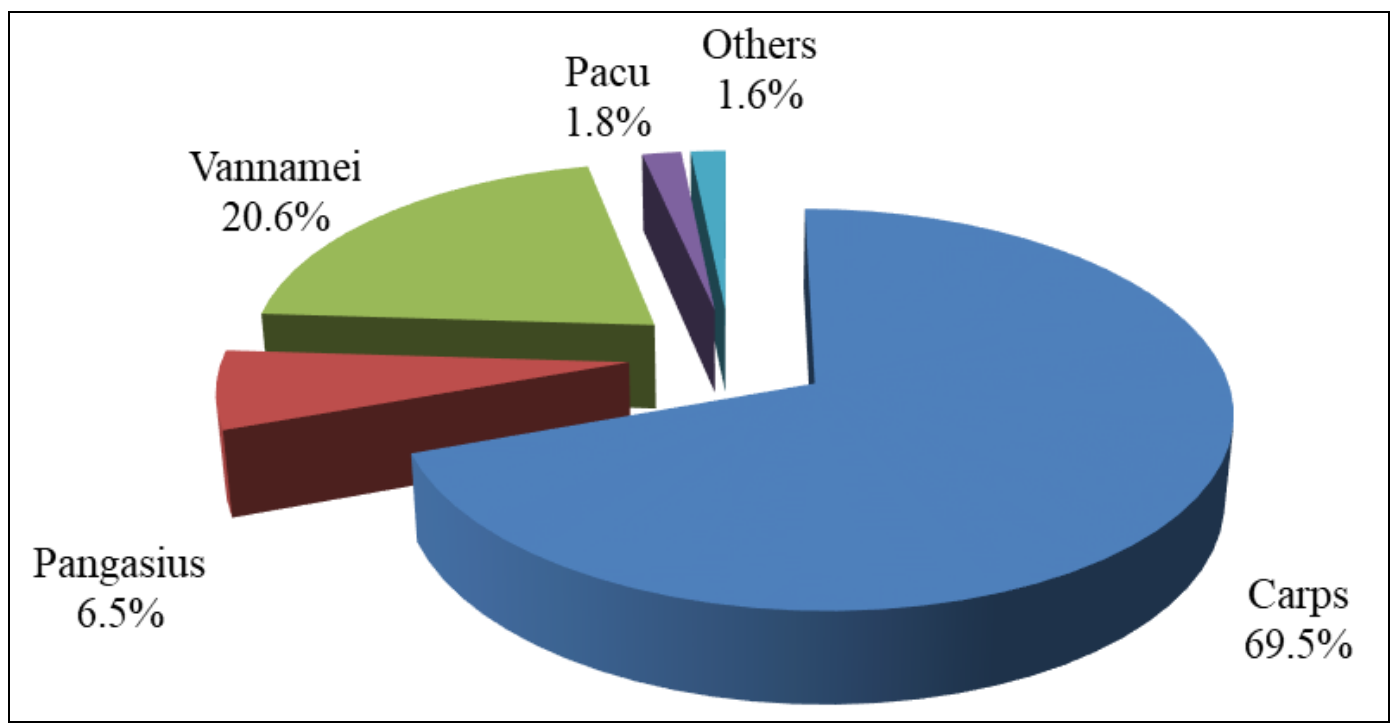

Fig 5: Pie chart showing preference of farmers towards farming of various species in Andhra Pradesh, India.

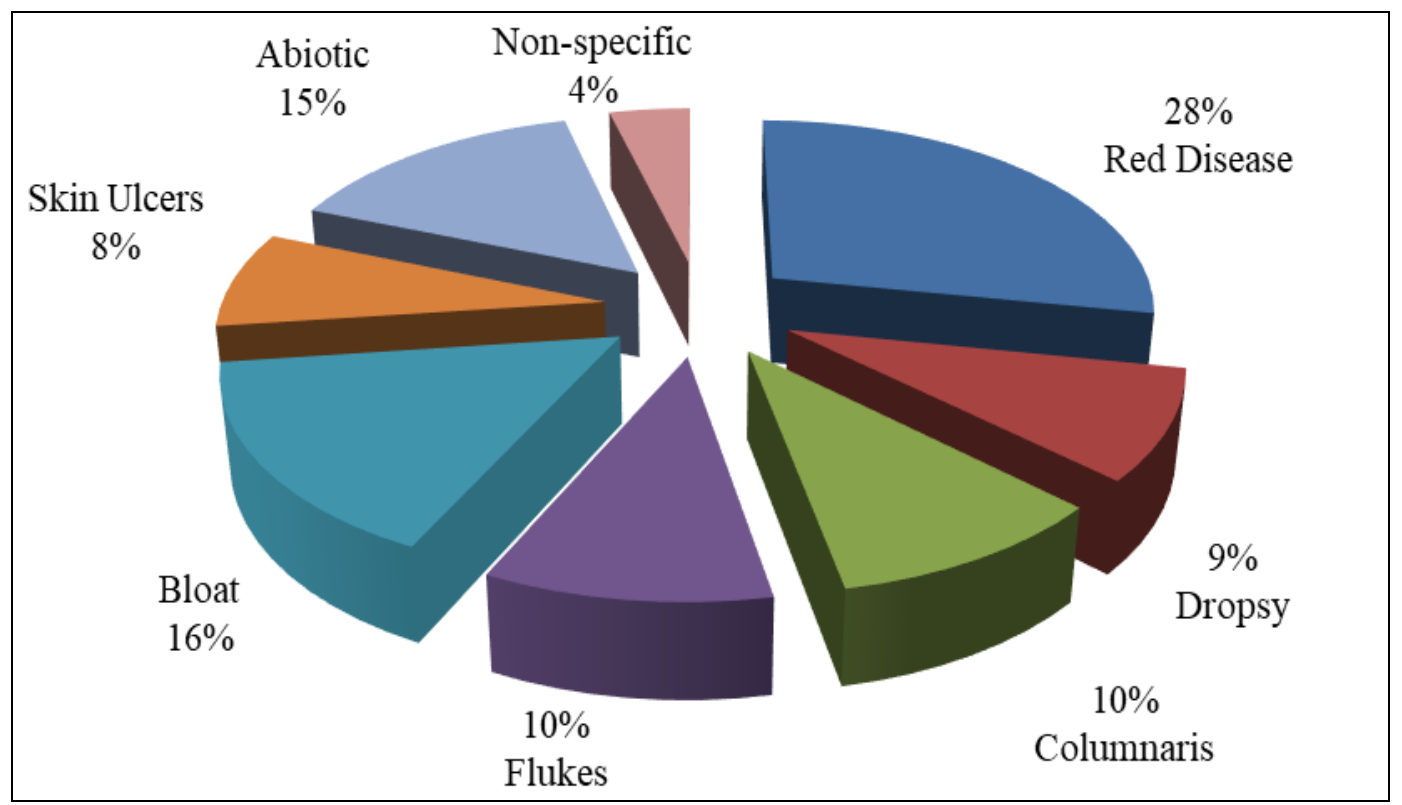

Fig 6: Pie chart showing various diseases encountered by farmers in Pangasius farming in Andhra Pradesh, India. 


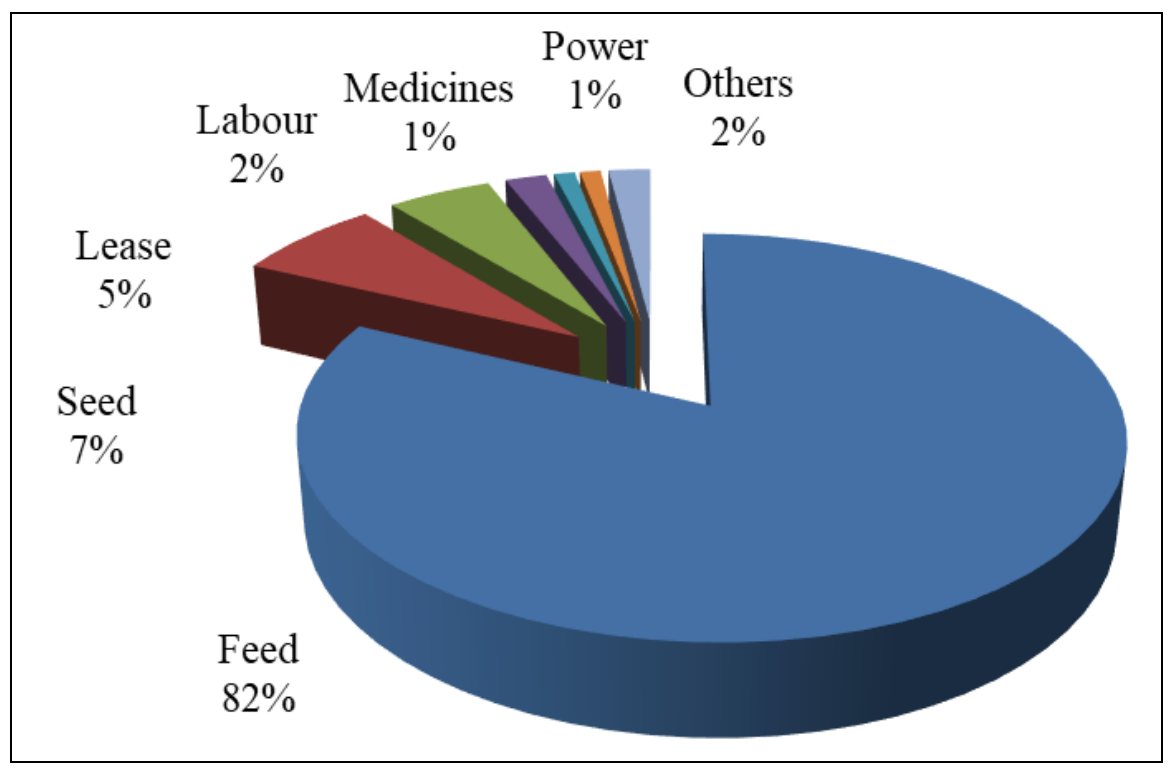

Fig 7: Pie chart showing determinants of production cost in Pangasius farming in Andhra Pradesh, India

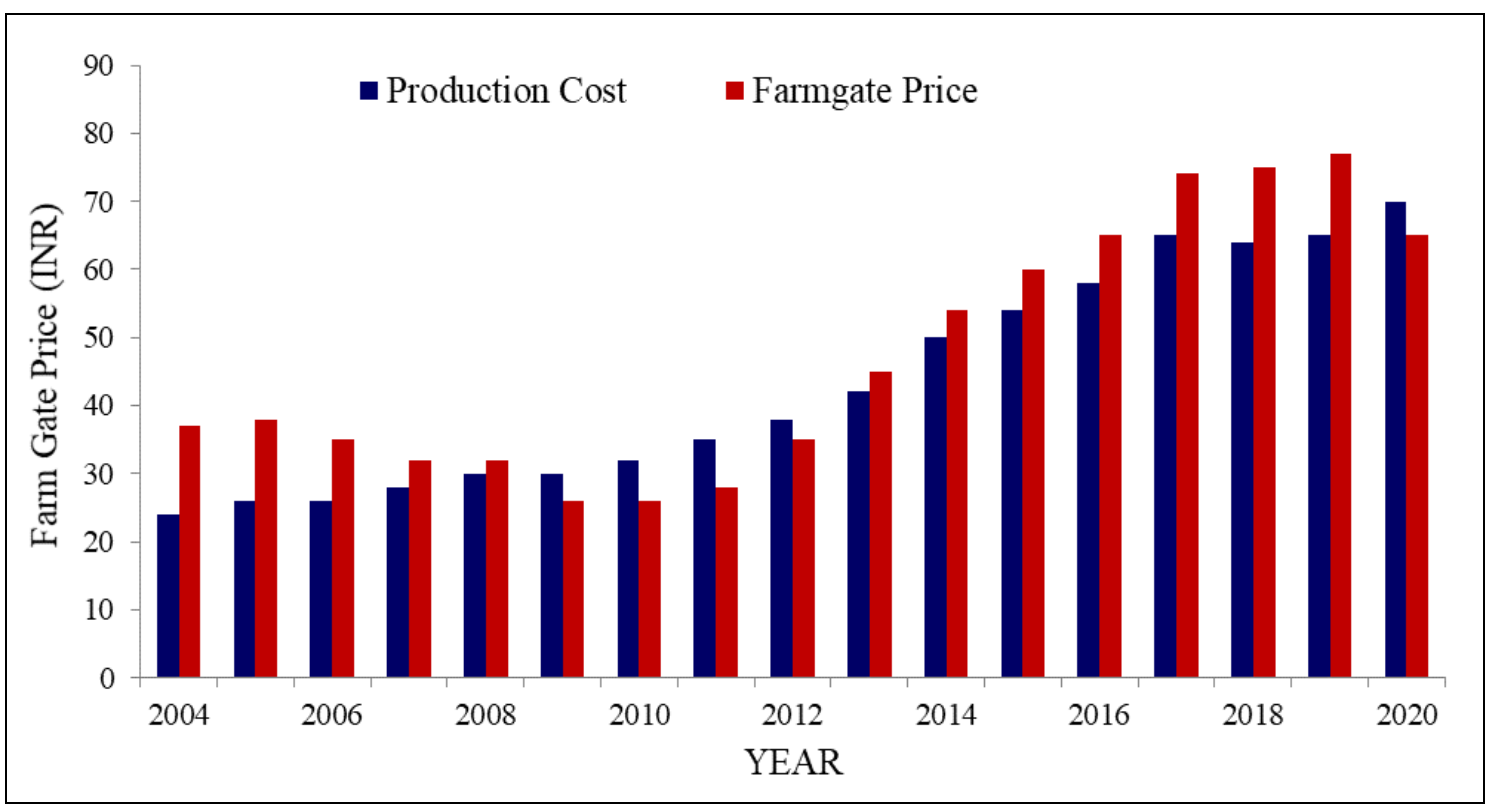

Fig 8: Histogram showing production cost and farm-gate price of Pangasius over the years in Andhra Pradesh, India

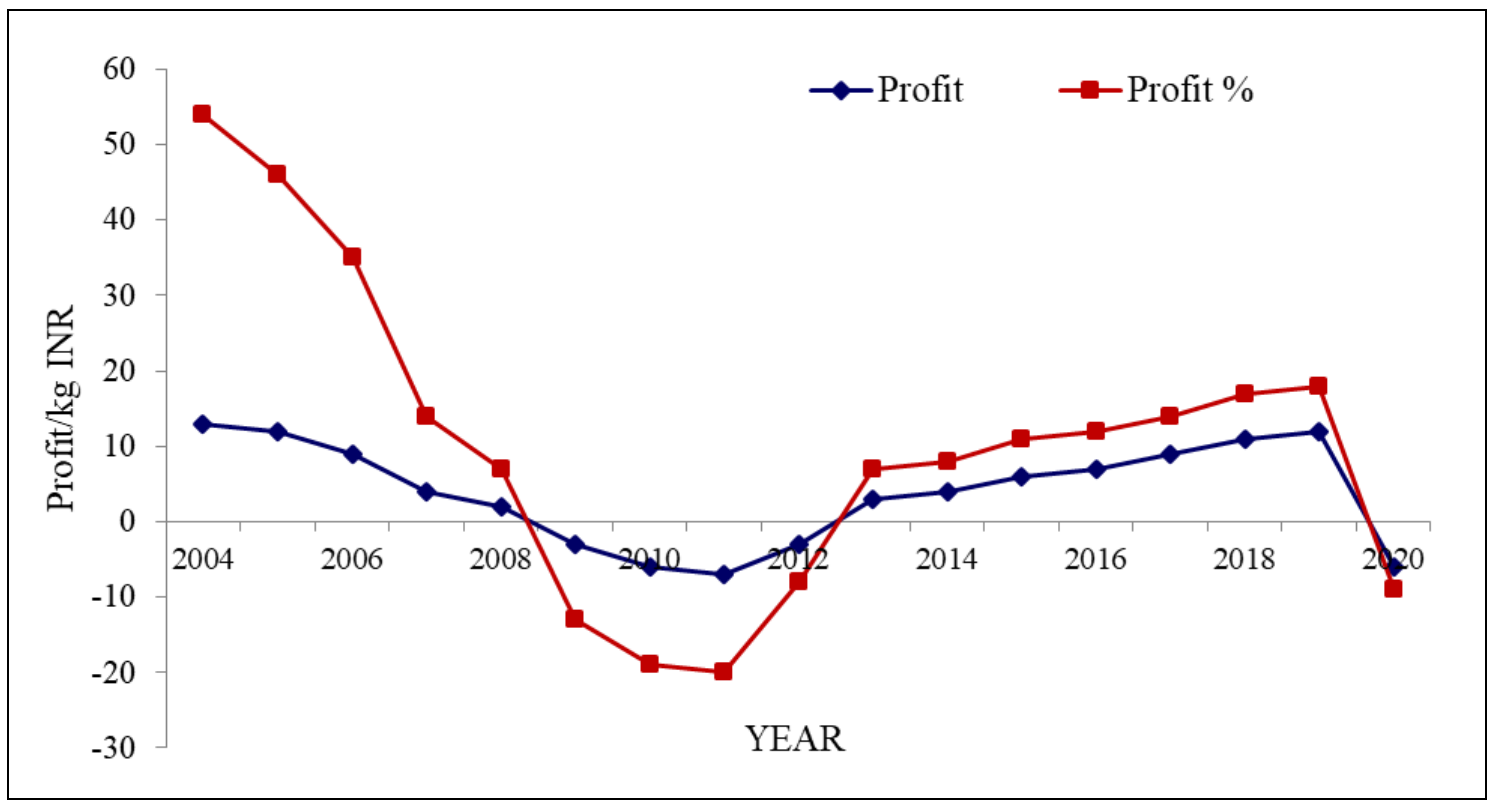

Fig 9: Line drawing showing profit and profit percent trend in Pangasius culture over the years in Andhra Pradesh, India. 


\section{Conclusion}

Although Pangasius catfish has established itself as a potential species of diversification in Andhra Pradesh, lack of appropriate advisories, inadequate use of capital assets and improper methods to achieve higher fish yield besides, pond area, feed costs and inconsistent market have become major challenges in assuring sustainability. Pangasius farming in the state continues to be robust due to competitive strategies adopted by farmers in seed stocking, harvesting and marketing besides minimizing the use of inputs to reduce risk factors. Thus, Pangasius breeding and indigenous seed production assume greater concern in order to minimize dependency for importing seed from outside agencies. Despite the fact that pangasius farming has become an important component in freshwater aquaculture in Andhra Pradesh, it is interesting to record that demand for carp culture in Andhra Pradesh remains greater.

\section{Acknowledgments}

Authors thank Dr. J. K. Sundaray, Head, FGBD, ICAR-CIFA for suggesting the topic of interest. We are grateful to the stake holders and representatives of aquaculture sector for participating in the survey and providing field information that helped in presenting real-time situation in this communication. We are also thankful to all the authors whose works are referred in compiling, describing and interpreting the data in this communication. Part of this work was supported by National Fisheries Development Board, Hyderabad which is duly acknowledged.

\section{References}

1. Kumar AB. Exotic fishes and freshwater diversity. Zoos Print Journal 2000;15(11):363-367.

2. Singh AK, Lakra WS. Culture of Pangasianodon hypophthalmus into India: Impacts and Present Scenario. Pakistan Journal of Biological Sciences 2012;15:19-26.

3. Raman RP, Mishra A, Kumar S, Sahay S, Bhagat MN, Kumar S. Introduction of exotic fish species into Indian Waters: An overview of benefits, issues, impacts and management. Advances in Fisheries Research 2013;6:114.

4. De Silva SS. Exotic aquatic organisms in Asia. In: De Silva, S. S. (Ed.), Proceedings of Workshop on Introduction of Exotic Aquatic Organisms in Asia. Asian Fisheries Society Special Publication No. 3, Manila, Philippines 1989, 154.

5. Rafferty JP. Invasive species. Encyclopædia Britannica 2019;2:7. https://www.britannica. com/science/invasivespecies.

6. Nyman L. Conservation of freshwater fish. Protection of biodiversity and genetic variability in aquatic ecosystems. In: Fisheries Development Series 56, Swedmar \& WWF, Sweden 1991, 38.

7. Philipp DP, Epifanio JM, Mardsen JE, Claussen JE. (Eds.). Protection of Aquatic Biodiversity. In: Proceedings of the World Fisheries Congress. Theme 3, Oxford and IBH Publ. Co., New Delhi 1995, 282.

8. Ramakrishna R, Shipton TA, Hassan MR. Feeding and feed management of Indian major carps in Andhra Pradesh, India. FAO Fisheries and Agriculture Technical 2013;90:578,

9. Belton B, Padiyar A, Ravibabu G, Gopal Rao K. Boom and bust in Andhra Pradesh: Development and transformation in India's domestic aquaculture value chain. Aquaculture 2017;470:196-206.

10. Palmatier RW, Houston MB, Hulland J. Review articles: purpose, process, and structure. Journal of the Academy of Marketing Sciences 2018;46:1-5. https://doi.org/10.1007/s11747-017-0563-4.

11. Krueger RA, Casey MA. Focus Groups. A Practical Guide for Applied Research (3 ${ }^{\text {rd }}$ Edition). Thousand Oaks, CA: Sage Publications 2000, 206.

12. Benedetti R, Marco B, Giuseppe E, Federica P. Agricultural Survey Methods. John-Wiley ISBN: 978-0470-74371-3, 2010, 434.

13. Jhingran VG. Fish and Fisheries of India. Hindustan Publishing Corporation, Delhi 1991, 727.

14. Choudhury R, Goswami UC. The introduction of exotic fishes in India and its implications in north-east India and Assam in particular. Proceedings of Zoological Society of India 2012, 81-88.

15. Sugunan VV. Reservoir Fisheries. In: Handbook of Fisheries and Aquaculture (Trivedi TP Ed.). New Delhi: Indian Council of Agricultural Research 2011, 239-274.

16. Pillai NGK, Katiha PK. Profile of Inland Aquaculture and Fisheries Technologies. In: Modayil MJ (Ed.) Evolution of Fisheries and Aquaculture in India, Pub. CMFRI, Kochi 2004, 43-96.

17. Soranganba N, Saxena A. Morphometric patterns of carps. Brazilian Journal of Morphological Sciences 2007;24(2):82-87.

18. Bhattacharjya B, Bhaumik UK, Sharma AP. Fish habitat and fisheries of Brahmaputra River in Assam, India. Aquatic Ecosystem Health \& Management 2017;20(1,2):102-115.

DOI: $10.1080 / 14634988.2017 .1297171$

19. Sarkar UK, Sharma J, Mahapatra BK. A Review on the Fish Communities in the Indian Reservoirs and Enhancement of Fisheries and Aquatic Environment. Journal of Aquaculture Research \& Development 2015;6:297.doi:10.4172/2155-9546.1000297.

20. Bhatt BV, Singh TK. Introduction of Exotic Aquatic Species For Aquaculture In India: Some Perspectives. In: Aquaculture: New Possibilities and Concerns (Ed. Sinha VRP, Jayasankar P), Narendra Publishing House, Delhi, India 2014, 157-172.

21. Jena JK, Gopalakrishnan A. Aquatic Biodiversity Management in India. Proceedings of National Academy of Sciences, India, Section B Biological Sciences 2011;S2:363-379.

22. Hussan A, Tanmoy GC, Das A, Gita S. Suckermouth Sailfin Catfishes: A future threat to aquatic ecosystems of India. Aquaculture Times 2016;2(6):20-22.

23. Singh AK. Emerging alien species in Indian aquaculture: prospects and threats. Journal of Aquatic Biology \& Fisheries 2014;2:32-41.

24. Meena M, Sundaramanickam A, Ajithkumar TT. Occurrence of a Pterygoplichthys disjunctivus (Weber, 1991) population in Cauvery River System, Tamil Nadu, South India. International Journal of Fisheries and Aquaculture 2016;8(6):62-66.

25. Ayyappan S, Jena JK, Lakra WS, Srinivasa Gopal TK, Gopalakrishnan A, Vass KK et al. Fisheries SciencesHistorical Perspective and Research Trends. In: Ed. Singh RB. 100 years of Agricultural Sciences in India, Pub: National Academy of Agricultural Sciences, New Delhi, India 2015, 330-410.

26. NFDB. Guidelines for regulating Introduction of 
Pangasius sutchi in India 2009, 17-26. http://fisheries.upsdc.gov.in/Uploads/nfdb Guideline.pdf

27. Chatopadhyay NR. Induced Fish Breeding: A Practical Guide for Hatcheries. Publisher, Academic Press 2016, 370.

28. Padiyar A, Ravibabu G, Gopal Rao K, Murthy CK. Pangasius market of AP: an analysis. Fishing Chimes 2014;33(10, 11):72.

29. Mugaonkar P, Kumar NR, Shelar G, Biradar RS, Gopalrao K. Delineation of Supply Chain of Pangasius in India-A Case of Andhra Pradesh. Current World Environment 2016;11(3):907-915.

30. Jayasankar P, Giri, BS. Striped catfish (Pangasianodon hypophthalmus) - Gift from Vietnam to Indian aquaculture industry. Fishing Chimes 2013;33(1, 2):3640.

31. Griffiths D, van Khanh P, Trong TQ. Cultured Aquatic Species Information Programme. Pangasius hypophthalmus. Cultured Aquatic Species Information Programme. In: FAO Fisheries and Aquaculture Department 2010, 10.

32. Ali MH, Haque MM, Belton B. Striped catfish (Pangasianodon hypophthalmus, Sauvage, 1878) aquaculture in Bangladesh: an overview. Aquaculture Research 2013;44(6):950-965.

33. Tam BM, Phan LT, Ingram BA, Thuy TTN, Gooley JG, Hao VN et al. Seed production practices of striped catfish, Pangasianodon hypophthalmus in the Mekong Delta region, Vietnam. Aquaculture 2010;306:92-100.

34. Mugaonkar PK, Kumar NR, Biradar RS. Economics and Determinants of Pangas catfish Production in India. Fishery Technology 2019;56:80-88.

35. Alam MF. Measuring technical, allocative and cost efficiency of pangas (Pangasius hypophthalmus) (Sauvage 1878) fish farmers of Bangladesh. Aquaculture Research 2011;42:1-14.

36. ICAR Reporter. New CIFA Technologies Released at New Delhi. https://icar.org.in/node/5548. 2013;29:8.

37. Nair MK, Salin KR. Carp polyculture in India - Practices, Emerging Trends. Global Aquaculture Advocate 2007;9(1, 2):55-57. https://www.researchgate.net/publication/ 235661633.

38. Ali MM, Asif AA, Shabuj Md AI, Suvashis V, Zafar Md A, Newaz Sharif BM. Status of polyculture Pangasius hypophthalmus with Carps in Jhikargacha Upazila of Jessore District, Bangladesh. International. Journal of Fisheries and Aquatic Studies 2016;4(1):423-430.

39. Azad MAK, Rahaman MA, Kader MA, Haque MM, Alam MJ. Polyculture of Carp, Tilapia \& Pangasus low cost inputs. Pakistan Journal of Biosciences 2004;7(11):1918-1926.

40. Shafiullah M, Siddique MAB, Rahman MS, Balaram M, Ali A, Rahmatullah MS. Effect of different stocking ratios on the production and survival of indigenous carps and pangas (Pangasius hypophthalmus) in a pond system. International Journal of Fisheries and Aquatic Studies 2019;7(1):19-24.

41. Islam MS, Haq KA, Rahman MA. Polyculture of Thai pangus (Pangasius hypophthalmus, Sauvage 1878) with carps and prawn: A new approach in polyculture technology regarding growth performance and economic return. Aquaculture Research 2008;39(15):1620-1627.

42. Ali ML, Haque SM, Borski RJ. The Culture Potential of Pangasius catfish in Brackish (Hyposaline) Waters of the
Greater Barishal Regions in Southern Bangladesh. Production System Design and Best Management Alternatives./13BMA02NC 2015, 1-14.

43. Castaneda R, Montoya-Ospina R, McGee M, Velasco M. Pangasius juveniles tolerate moderate salinity in test. Global Aquaculture Advocate 2010; 3\&4:27-28.

44. Jahan A, Nipa TT, Islam SMM, Helaluddin MI, Shajjahan M. Striped catfish (Pangasianodon hypophthalmus) could be suitable for coastal aquaculture. Journal of Applied Ichthyology 2019;35(4):994-1003.

45. Khan A, Guttormsen A, Roll KH. Production risk of pangas (Pangasius hypophthalmus) fish farming. Aquaculture Ecology \& Management 2017;22:192-208.

46. Ngoc PY, Gaitán-Cremaschi D, Miranda PM, Le TC, Bosma, RH. Technical inefficiency of Vietnamese pangasius farming: A data envelopment analysis. Aquaculture Ecology \& Management 2018;22:229-243.

47. Singh AK. Apprehensions and issues related to pacu Piaractus brachypomus (Cuvier 1818) farming in India. Journal of Fisheries Research 2018;2(2):19-23.

48. Lakra WS, Singh AK. Risk analysis and sustainability of Pangasianodon hypophthalmus culture in India. Genetics and Bio-diversity 2010;15(1):35-37.

49. Swain S. Exotic Fish Species Introduced In India and Its Impacts. Scientific India 2017, 27-29.

50. Singh AK, Lakra WS. Risk and benefit assessment of alien fish species of the aquaculture and aquarium trade into India. Reviews in Aquaculture 2011;3:3-18.

51. Dung TT, Nguyen TNN, Nguyen QT, Dang TMT, Tuan NA, Andrew S, Crumlish M. Common diseases of pangasius catfish farmed in Vietnam. Global Aqua. Aliance 2008;7:1.

52. Faruk MAR. Disease and health management of farmed exotic catfish Panagasius hypopthalmus in Mymensingh district of Bangladesh, pp. 193-204. In Bondad-Reantaso, MG, Mohan CV, Crumlish M, Subasinghe RP (eds.). Diseases in Asian Aquaculture VI. Fish Health Section, Asian Fisheries Society, Manila, Philippines 2008, 505.

53. Mishra SS, Das R, Swain P. Status of fish diseases in aquaculture and assessment of economic loss due to diseases. In: Rao PN, Pandey BN, Pandey PN, Joshi, BD (Eds.). Contemporary trends in Fisheries and Aquaculture, Today \& Tomorrow Publishers, New Delhi, 2018, 183-199.

54. Sahoo PK, Mohanty J, Garnayak SK, Mohanty BR, Jena JK. Estimation of loss due to argulosis in carp culture ponds in India. Indian Journal of Fisheries, 2013;60(2):99-102.

55. Baska F, Voronin VN, Eszterbauer E, Müller L, Szilvia $\mathrm{M}$, Molnár K. Occurrence of two myxosporean species, Myxobolus hakyi sp. n. and Hoferellus pulvinatus sp. n., in Pangasianodon hypophthalmus fry imported from Thailand to Europe as ornamental fish. Parasitology Research 2009, 2013;105:1391-8. 10.1007/s00436-0091567-x.

56. Molnar K, Székely C, Mohamed K, Shaharom FM. Myxozoan pathogens in cultured Malaysian fishes. I. Myxozoan infections of the sutchi catfish Pangasius hypophthalmus in freshwater cage cultures. Diseases of Aquatic Organisms 2006;68:209-218.

57. Mishra SS, Das R, Dhiman M, Choudhary P, Debbarma J, Sahoo SN et al. Present Status of Fish Disease Management in Freshwater Aquaculture in India: Stateof-the-Art-Review. Journal of Aquaculture \& Fisheries, 
2017;1:3-12.

58. Khiem NT, Bush SR, Chau NM, Loc VTT. Upgrading small-holders in the Vietnamese Pangasius value chain. Final Report, ODI grant number RO334. An Giang University, Wageningen University and Can Tho University 2010, 158.

59. Kader MA, Hossain MA, Hossain MD. A comparative study on the effect of commercial fish feeds on the growth of Thai pangas, Pangasius hypophthalmus. Bangladesh Journal of Fisheries Research 2003;7(1):5358.

60. Sayeed MAB, Hossain GS, Mistry KA, Huq SK. Growth performance of Thai pangas (Pangasius hypophthalmus) in polyculture system using different supplementary feeds. University Journal of Zoology Rajshahi University 2009;27: DOI: 10.3329/ujzru.v27i0.1956.

61. Nguyen TP. On-farm feed management practices for striped catfish (Pangasianodon hypophthalmus) in Mekong River Delta, Viet Nam. In: Hasan MR, New MB eds. On-farm feeding and feed management in aquaculture. FAO Fisheries and Aquaculture Technical Paper No. 583, Rome, FAO. 2013, 241-267.

62. Tran TTH, Nguyen TP, Tran LCT, Glencross B. Assessment of methods for the determination of digestibilities of feed ingredients for digestibilities of feed ingredients for tra catfish, Pangasianodon hypophthalamus. Aquaculture Nutrition 2010;16:351358.

63. Da CT, Hung LT, Berg H, Lindberg JE. Evaluation of potential feed sources, And technical and economic considerations of small-scale commercial striped catfish (Pangasius hypothalamus) pond farming systems in the Mekong Delta of Vietnam. Aquaculture Research 2013;44(3):427-438.

64. Le TH, Pham VH. Feed and feeding practice for Pangasius cultured in the Mekong River Delta. Scientific Journal of Can Tho Special issue on Aquaculture and Fisheries 2006;4:144-151.

65. Faruk M, Rahman N, Patwary Z. Risk factors associated with tilapia and pangasius diseases. Journal of Bangladesh Agriculture University 2017;15(2):325-331.

66. Khan S, Hossain MS, Haque MM. Effects of feeding schedule on growth, production and economics of pangasiid catfish (Pangasius hypophthalmus) and silver carp (Hypophthalmichthys molitrix) polyculture. Journal of Bangladesh Agriculture University 2009;7(1):175-181.

67. Ahmed GU, Chakma A, Shamsuddin Md, Hossain MM, Islam T, Zihad MM. Growth performance of Thai Pangus (Pangasianodon hypophthalmus) using prepared and commercial feed. International Journal of Life Sciences, Biotechnology \& Pharmacy Research 2013;2(3):2-13.

68. Jayasankar P. Review Present status of freshwater aquaculture in India - A review. Indian Journal of Fisheries, 2018;65(4):157-165. DOI: 10.21077/ijf. 2018.65.4.81300-20.

69. Saravanan K, Prabhu AJP, Biju SKJ. Feeding strategies adopted by fish farmers in Andhra Pradesh, India. Aquaculture 2012;17(1):21-24.

70. Shurson J. A look at corn distillers dried grains with soluble. Global Aquaculture Alliance 2012;7:2. https://www.aquaculturealliance.org/advocate/a-look-atcorn-distillers-dried-grains-with-solubles/

71. Lim C, Aksoy MY. Distillers dried grain with solubles as an alternative protein source in fish feeds. $8^{\text {th }}$ Intl.
Symposium on Tilapia in Aquaculture 2008, 67-82.

72. Banrie B. Summary of Distillers Grains Studies for PondRaised Catfish. The Fish Site 2013;20:5. https://thefishsite.com/articles/summary-of-distillersgrains-studies-for-pondraised-catfish

73. Wadhwa M, Bakshi MPS. Application of Waste-Derived Proteins in the Animal Feed Industry. In: (Ed.) Dhillon GS, Protein Byproducts: Transformation from Environmental Burden Into Value-Added Products, 2016, 333-341. Academic Press, Canada.

74. Bailey T. Premium New and rare Albino Pangasius Catfish. Aquarium Fish. 2021. https://aquariumfish.ecwid.com/Premium-New-and-RareAlbino-Pangasius-Catfish p147450953

75. McGee MV, Pangasius For Western Aquaculture. The Fish Site 2010, 13(11).

https://thefishsite.com/articles/pangasius-for-westernaquaculture

76. Gupta S, Banerjee S. Indigenous ornamental fish: a new boon in ornamental fish trade of West Bengal. Fishing Chimes 2012;32:130-134.

77. Axelord HR, Leonard LP. Hand Book of Tropical Aquarium Fishes. TFH Publications ISBN 0-87666-5431. 1996, 718p.

78. Merican Z. Aquafeeds in 2019: Pulled by market demand. Aquaculture in Asia Pacific 2019;16:24-29.

79. Mohan ABCH, Gopal Rao K, Ravibabu G. Recent Trends in Pangasius, Pangasianodon hypophthalmus farming, production and marketing in India. Asia-Pacific Aquaculture, Chennai, India 2019, 9-11.

80. Thong NT, Ankamah-Yeboah I, Bronnmann J, Nielsen M, Roth E, Birgit Schulze E. Price transmission in the pangasius value chain from Vietnam to Germany. Aquaculture Reports 2020;16:23-30.

81. Mugaonkar P, Kumar NR, Shelar G, Shete A. Pangasius aquaculture growing in India. Global Aquaculture Advocate 2017;11:1-5.

https://www.aquaculturealliance.org/ advocate/ pangasius-aquaculture-in-india/

82. Hasan MR, Shipton TA, Bueno PB. Aquafeed value chain analysisand a review of regulatory framework of striped catfish farming in Viet Nam. FAO Fisheries and Aquaculture Technical Paper Rome, FAO. 2019;648:71.

83. Pandit S, Raul C. Introductions of Exotic fish Species and its Prospectus in Indian Waters. Aqua International 2019;1:52-64.

84. Sarkar UK, Sandhya KM, Mishal P, Karnatak G, Lianthuamluaia the KS, Panikkar $\mathrm{P}$ et al. Status, Prospects, Threats, and Way Forward for Sustainable Management and Enhancement of the Tropical Indian Reservoir Fisheries: An Overview, Reviews in Fisheries Science and Aquaculture 2017. DOI: $10.1080 / 23308249.2017 .1373744$

85. Khan MHL, Mollah MFA. Further trials on induced breeding of Pangasianodon pangasianodon (Hamilton) in Bangladesh. Asian Fishery Science 2004;17:135-146.

86. Hossain MY, Rahman MM, Mollah MFA. Threatened fishes of the world: Pangasianodon pangasianodon Hamilton-Buchanan, 1822 (Pangasiidae). Environmental Biology Fisheries 2019;84:29-31.

87. Laxmappa B. Weighing the risks of farming non-native fish species in India. Global Aqua Advocate 2016, www.aquaculturealliance.org/advocate/weighing-therisks-of-farming-non-native-fish-species-in-india/ 
88. Kummari S, Prakash BCH, Prasad MS, Narshivudu D, Suresh G. Opportunities and prospects of inland freshwater aquaculture in Telangana: A step towards blue revolution. Journal of Entomology and Zoology Studies 2017;6(3):314-319.

89. Bhendarkar MP, Sundaray JK, Ananth PN, Pradhan S. Aquaculture Development in Chhattisgarh, India: What, why and how?. International Journal of Fisheries and Aquatic Studies 2017;5(4):272-278.

90. Kumar V, Karnatak G, Mishal P, Das AK, Hassan MA, Sharma AP. Potential Species for Cage Aquaculture in Indian Reservoirs. World Aquaculture 2015;9:46-48. www.was.org.

91. Jacob TC, Suresh VR, Sugunan VV, Meenakumari B. Conservation of aquatic biodiversity for achieving india's food, nutritional and livelihood security with special reference to inland fisheries and aquaculture. Journal of Fisheries Research 2020;4(1):31-36.

92. NFDB. Guidelines for cage culture in inland open water bodies of India. National Fisheries Development Board, Hyderabad 2016, 20.

93. Hughes AC. Understanding the drivers of Southeast Asian biodiversity loss. Ecosphere 2017;8(1):e01624. 10.1002/ecs2.1624.

94. Zeng L, Zhou L, Li-Guo D, Dong-Hua F, Xu P, Zeng S et al. Ecological effects of dams, alien fish, and physiochemical environmental factors on homogeneity/ heterogeneity of fish community in four tributaries of the Pearl River in China. Ecology \& Evolution 2017;7(11):3904-3915.

95. Giri BS, Mishra SS, Swain SK, Pillai BR, Satyavathi CH, Sravanthi Y et al. Suckermouth armoured catfish (Pterygoplichthys spp.) menace in freshwater aquaculture and natural aquatic systems in Andhra Pradesh, India. International Journal of Fisheries and Aquatic Studies 2021;9(1):375-384.

96. Chaichana R, Sirapat J. Assessment of the invasive catfish Pterygoplichthys pardalis (Castelnau, 1855) in Thailand: ecological impacts and biological control alternatives. Journal of Tropical Zoology 2012;25(4):4962. 